http://dx.doi.org/10.4314/jae.v18i1.3

\title{
Women Farmers' Perception and Utilization of Marketing Information on Cassava in Osun State, Nigeria.
}

\author{
Olaniyi, O.A. and Adewale, J.G. \\ Department of Agricultural Extension and Rural Development, \\ Ladoke Akintola University of Technology, \\ P.M. B 4000, Ogbomoso, Oyo State, Nigeria. \\ E Mail : oaolaniyi@lautech.edu.ng \\ Phone Number: +2348060202639
}

\section{Abstract}

The study ascertained the perception of women farmers' on utilization of marketing information on cassava in Osun State, Nigeria.Multistage sampling technique was adopted in the selection of 110 women cassava farmers in Osun State. Data were collected from the women with the aid of structured interview schedule .Data analysis was carried out using frequency counts, percentages, mean, standard deviation and Spearman rho correlation was used to establish relationships between selected variables. The identified sources of marketing information include: radio, husbands, extension agents and Cassava Growers Association. The most utilized marketing information was information on market days and market distance (WMS= 4.61) followed by information on best time to sell Cassava produced (WMS $=4.48)$ and information on preferred varieties of Cassava that attract high market price (WMS= 4.46) among others The women farmers were favourable in their perception on utilization of marketing information. Years of education $(r=-0.238, P<0.05)$; farming experience $(r=0.654, P<0.05)$ significantly influenced perception of women farmers on utilization of marketing information on cassava. It was recommended that the dissemination of marketing information by extension institutions be made available to women farmers in Osun State through the preferred sources of information such as radio, husbands and Cassava Growers Association.

Key words: Cassava marketing utilisation, women farmers.

\section{Introduction}

Agricultural marketing information is an important and new aspect of agriculture in developing countries. This is known to have a great potential of promoting agricultural products both locally and internationally (Oyeyinka and Bello, 2013). The main stay of Nigerian economy is agriculture which at the same time is a major source of income for majority of rural population (Sakia and Barman, 2013). The participation of women as an important segment of rural population in agriculture is germane to sustainable agricultural development. Hence, promoting access to and utilization of various categories of agricultural information that can support farmers and rural development therefore plays an important role in the social and economic development of a nation (Mangual, 2010). The contributions of women in agriculture are poorly understood and their specific information needs are ignored in the development planning. In spite of that, women are the world's 
principal food producers and provider (Nosheen et al, 2008). Women have been found to play active roles in agricultural production in Nigeria especially in activities such as production, processing and marketing of produce.

According to Ogunlela and Muktar (2009) agriculture in Africa especially in Nigeria is essentially is at subsistence level, yet the surpluses are sold in the market by farmers to make money. Farmers that are involved in export crops needs marketing information for profit maximization. As noted by Yahaya and Akinboye (1999) that one of the basic objective of agricultural information is that it helps in solving problems faced by farmers. For this to be possible, it must be relevant to the users at any given time.

Interestingly, information has become one of the most important factors of production, and there is no doubt that this trend will continue. In this present information age, it is knowledge accumulation and application that will drive development and create unprecedented opportunities for economic growth and for poverty reduction. It has been estimated that the effective integration of information and communications technologies (ICTs) in different sectors of the economy will augment economic growth rates by $2-3 \%$. Having timely and relevant information especially marketing information on transport availability, new marketing opportunities, and the market prices of farm inputs and outputs is fundamental to an efficient and productive agricultural economy (Samuel, 2001; Adebo and Ewuola, 2005).

Cassava (Manihot esculenta) is a major food crop in Nigeria. It is a major staple food and source of dietary energy for most low income families in rural and urban areas. The recent initiatives by the Federal Government on cassava production have opened the eyes of many to the cultivation of cassava as a crop. There is therefore the need to provide farmers with adequate information on marketing outlets for cassava. The effectiveness and efficient use of marketing information by women farmers is expected to ultimately lead to profit maximization, increased income and poverty reduction. It is therefore pertinent to ascertain the perception of women farmers on the utilization of marketing information on cassava. Specifically, the study intended to:

i. determine the socio-economic characteristics of women farmers in the study area

ii. ascertain the sources of marketing information available to women farmers

iii. ascertain the available marketing information to women farmers.

iv. investigate the extent of utilization of marketing information on cassava among women farmers.

v. determine the perception of women farmers on utilization of marketing information on cassava.

\section{Hypothesis}

Based on the objectives of the study this null hypothesis was stated

i. There is no significant relationship between women farmers' personal characteristics and perception of utilization of marketing information on cassava. 


\section{Methodology}

This study was carried out in Iwo agricultural zone of Osun State. The area shares boundaries with the Osun State capital, Osogbo and Ibadan, Oyo State capital. The area is situated at the North-East of Osun State and is geographically located at latitude $7^{\circ} 58^{\prime}$ North of the equator and longitude $4^{\circ} 28^{\prime}$ East of the Greenwich Meridian. The zone consists of six agricultural blocks, namely: Ayedire, Irewole Isokan, Ejigbo, Ola-Oluwa and Iwo. Agricultural activities being practiced in the area of crop production include yam, maize, cassava, millet, soybean, cowpea and vegetables. The climate is tropical with two distinct seasons. Usually, the wet season lasts between March and October while the dry season comes between November and February. Mean annual rainfall is between 2,000 and $2,200 \mathrm{~mm}$. Maximum temperature is $32.5^{\circ} \mathrm{C}$ while the relative humidity is $79.90 \%$.

Population and sampling: The population of the study comprised all registered women farmers producing cassava crop in Iwo agricultural zone area of Osun state.

Multi-stage sampling technique was employed to select 110 women farmers in the study area. In the first stage, 3 blocks (50\%) were randomly selected from the existing 6 blocks. Each block comprised eight cells. The sampling procedure further involves random selection of $50 \%$ of the cells 4 in each block making a total of 12 cells for the study. Thereafter, in the 3rd stage, $20 \%$ of the farmers' groups were selected at random. Finally, $10 \%$ of women farmers in each group were randomly sampled for the study. A total of 110 women cassava farmers formed the sample of the study. A structured interview schedule was used to collect primary data from sampled women farmers after carrying out content validity test and pre-tested for its reliability. Descriptive statistics such as frequency counts, percentages, mean, and chart was used for the data analysis. Spearman Rho correlation was used as inferential statistic to test the formulated hypothesis.

\section{Measurement of Variables}

Both the independent and dependent variables were measured in this study. The independent variables measured include: age, marital status, education, household size, religion, years of farming experience and membership of social organization. Utilization of marketing information was measured on a 3points scale of Never, $=0$ sometimes $=1$ and Always $=2$.

The perception of utilization of marketing information on cassava was operationalized using perception index. This was measured on a 5point Likert-type scale of Strongly Agreed (SA) $=5 ;$ Agreed $=4 ;$ Undecided $(U)=3$, Disagreed $(D S)=2$ and Strongly Disagreed $(S D)=1$.

Ten perception statements were presented to the respondents. The maximum score for a respondent was 50 points while the minimum score was 10 . Based on the mean score, the respondents were categorized into three, less favourable, favourable and more favourable.

\section{Results and Discussion}

\section{Personal Characteristics of the Respondents}

As seen in Table 1, majority (84.5\%) of the respondents are 40 and above years of age while others $(15.5 \%)$ are below 40 years of age. The mean age of the respondents was 
44.8years. This indicates that majority of the sampled respondents are in their active years; hence can contribute immensely is the productive sectors. Yahaya (2002) had earlier reported that women farmers are more active between the ages of 20 to 50 years.

Another section of the same table 1 revealed that a high percentage of the women are literate with majority $(51.8 \%)$ had senior secondary school education and followed by those that had primary school education (30.0\%). This finding contradicts the findings of Banmeke and Ajayi (2006) who reported low level of education among women farmers in southwest Nigeria. The contradiction could probably be attributed to the activities of the government in the state in improving the access of its inhabitants to quality education. Furthermore, majority (59.19\%) of the women farmers had a household size between 1 and 4 members followed by those respondents with household size between 5 and 8 members (26.4\%). This implies that the respondents had a relatively small household size which has implications for labour availability for the farm work. Majority (69.1\%) of the respondents had their years of farming experience to be less than 10 followed by those with years of farming experience between $10-20 y e a r s ~(26.4 \%)$ and others (4.5\%) had their farming experience to be 21years and above. High proportions (90.0\%) of the respondents were members of social organization while others $(10 \%)$ did not have any social affiliation in their communities.

In addition, majority (65.5\%) of the respondents cultivated between 1 and 5 acres of land for cassava followed by those that cultivated between 6 and 11 acres of land $(20.9 \%)$ and other cultivated between 11 and above acres of land. This means then they are small scale holder farmers. The result also revealed that majority (56.4\%) of the sampled women farmer are Islamic religion while $28.2 \%$ of the respondents are Christians and others $(15.5 \%)$ are of traditional religion. 


\section{Table1: Distribution of women farmers according to Personal characteristics}

\begin{tabular}{|c|c|c|}
\hline Variable & Frequency & Percentage \\
\hline \multicolumn{3}{|l|}{ Age (years) } \\
\hline Up to 30 & 4 & 3.6 \\
\hline $31-40$ & 13 & 11.8 \\
\hline 40 and above & 93 & 84.6 \\
\hline \multicolumn{3}{|c|}{ Years spent in school } \\
\hline 0 & 2 & 1.8 \\
\hline $1-6$ & 33 & 30.0 \\
\hline 7- 9 & 57 & 51.8 \\
\hline $10-13$ & 13 & 11.8 \\
\hline 14 and above & 5 & 4.4 \\
\hline \multicolumn{3}{|l|}{ Household size } \\
\hline $1-4$ & 65 & 59.1 \\
\hline $5-8$ & 29 & 26.4 \\
\hline $9-12$ & 16 & 14.5 \\
\hline \multicolumn{3}{|c|}{ Years of cassava farming } \\
\hline \multicolumn{3}{|l|}{ Experience } \\
\hline Less than or 10 & 76 & 69.1 \\
\hline $11-20$ & 29 & 26.4 \\
\hline 21 and above & 5 & 4.5 \\
\hline \multicolumn{3}{|c|}{ Membership of social } \\
\hline \multicolumn{3}{|l|}{ Organization } \\
\hline Yes & 99 & 90.0 \\
\hline No & 11 & 10.0 \\
\hline \multicolumn{3}{|c|}{ Cultivatable cassava } \\
\hline \multicolumn{3}{|l|}{ Farm size } \\
\hline $1-5$ & 72 & 65.5 \\
\hline $6-10$ & 23 & 20.9 \\
\hline $11-15$ & 7 & 6.4 \\
\hline 16 and Above & 8 & 7.2 \\
\hline \multicolumn{3}{|l|}{ Religion } \\
\hline Christianity & 31 & 28.2 \\
\hline Islam & 82 & 56.4 \\
\hline Traditional & 17 & 15.5 \\
\hline
\end{tabular}

Source: Field Survey, 2012

\section{Sources of Marketing Information on Cassava}

Table 2 shows that women farmers make use of different sources to have access to marketing information on cassava. Eleven sources of marketing information were identified by the respondents. A total of $100 \%$ of the respondents accessed marketing information from radio, and $100 \%$ from husband, followed by extension agents and cooperative societies (99.1\%) ; cassava grower association (95.5\%) and Television (77.2\%) 
respectively. Other sources of marketing information include: commercial input dealers (72.7\%); mobile phone (58.2\%); internet (31.8\%) and newspaper $(6.4 \%)$. This finding is in agreement with those of other authors ( Ajayi, 2003, Anigwe, 1990) who earlier reported radio, extension agents as leading sources of agricultural information to women farmers. It is worthy to note that modern ICT especially internet is the one of the least explored source of information is an indication that the respondents are still depend on traditional and conventional sources of information.

Table 2: Distribution of respondents according to sources of marketing information on cassava

\begin{tabular}{lll}
\hline Sources of Marketing & Frequency & Percentage \\
information &
\end{tabular}

\begin{tabular}{lll}
\hline Radio & $110^{*}$ & 100.0 \\
Television & 85 & 77.2 \\
Newspaper & 07 & 6.34 \\
Extension Agents & 109 & 99.1 \\
Friends / Neighbour & 105 & 95.5 \\
Mobile phone & 64 & 58.2 \\
Husband & 110 & 100.0 \\
Internet & 35 & 31.8 \\
Input Dealers & 80 & 72.7 \\
Cooperative societies & 109 & 99.1 \\
Cassava Growers Association & 105 & 95.5 \\
\hline
\end{tabular}

Sources: Field Survey, 2012

${ }^{*}$ Multiple response

\section{Availability and utilization of marketing information}

Table 3 shows majority (89.3\%) of the respondents claimed that information on market days/market distance were available and the most often utilized (WMS $=4.61)$ and ranked first, followed by the information on the best time for marketing harvested cassava tubers $(81.8 \%)$ and this ranked $2^{\text {nd }}(\mathrm{WMS}=4.48)$ and information on high yielding varieties for better market value $(80.9 \%)$ ranked $3^{\text {rd }}(\mathrm{WMS}=4.46)$. The least available and utilized marketing information include information on value addition on cassava (64.5\%), information on risks involved in cassava production (53.6\%) and exportation of raw/processed cassava (45.5\%). These items ranked $6^{\text {th }}, 7^{\text {th }}, 8^{\text {th }}$ respectively on the utilization of marketing information. This finding corroborates that of Olowu and Yahaya (1998) that women farmers were in need of current and future prices of commodities. 
Table 3: Availability of marketing information on cassava available and Utililization

\begin{tabular}{|c|c|c|c|}
\hline Marketing information on cassava & $\begin{array}{l}\text { Available } \\
\text { Yes }\end{array}$ & $\begin{array}{l}\text { Utilized } \\
\text { WMS }\end{array}$ & Rank \\
\hline The best time for marketing harvested cassava & $90(81.8)$ & 4.48 & $2^{\text {nd }}$ \\
\hline The available market to sell cassava produced & $81(73.6)$ & 4.37 & $4^{\text {th }}$ \\
\hline $\begin{array}{l}\text { Information on the cheapest form of transportation } \\
\text { of cassava tubers }\end{array}$ & $82(74.5)$ & 4.11 & $5^{\text {th }}$ \\
\hline $\begin{array}{l}\text { Information on value addition on cassava to } \\
\text { enhance market price }\end{array}$ & $71(64.5)$ & 3.89 & $6^{\text {th }}$ \\
\hline Exportation of cassava produced raw or processed & $50(45.5)$ & 3.38 & $8^{\text {th }}$ \\
\hline Information on risks involved in cassava production & $59(53.6)$ & 3.65 & $7^{\text {th }}$ \\
\hline $\begin{array}{l}\text { Information on high yielding varieties for better } \\
\text { market value }\end{array}$ & $89(80.9)$ & 4.46 & $3^{\text {rd }}$ \\
\hline Information on market days/ market distance & $96(87.3)$ & 4.46 & $1^{\text {st }}$ \\
\hline
\end{tabular}

\section{Sources: Field Survey, 2012}

\section{Perception of utilization of marketing information}

Table 4 revealed that utilization of marketing information on cassava has increased may income $(\mathrm{WMS}=4.58)$ and was ranked $1^{\text {st }}$ followed by the perception statement that utilization of marketing information on cassava improved the knowledge of better future prices to sell cassava produced (WMS $=4.53$ ). The statement that "availability of marketing information exposed me to better marketing outlets" (WMS=4.50); "the knowledge of marketing information helps to reduce the risk with cassava marketing" (WMS=4.35); "availability of marketing information through the extension agents is an incentive to produce more cassava every year" $(\mathrm{WMS}=2.56)$, ranked $3 \mathrm{rd} 4^{\text {th }}$ and $5^{\text {th }}$ respectively. The perception statements with the least Weighted Mean scores include: marketing information are not made available when needed hence I cannot use it (WMS=2.40); bad road condition is highly discouraging to sell cassava produced at market (WMS=2.33); and I don't have opportunity to international market for cassava produced $(\mathrm{WMS}=2.07)$ ranked $6^{\text {th }}, 7^{\text {th }}$ and $8^{\text {th }}$ respectively. Others are: marketing information on value addition is confusing hence I don't use (WMS=1.67) and there is no significant improvement on my economic gain as a result of utilization of marketing information on cassava (WMS $=1.51$ ). This finding implies that the respondents perception on utilization of marketing information on cassava affects on the lives of women farmers. 
Table 4: Distribution of respondents by perception on utilization of marketing information

\begin{tabular}{lcc}
\hline Perception statements & Weighted Mean Score (WMS) & Rank \\
\hline $\begin{array}{l}\text { Utilization of marketing information on } \\
\text { cassava has increases my income }\end{array}$ & 4.58 & $1^{\text {st }}$ \\
$\begin{array}{l}\text { Utilization of marketing information on } \\
\text { cassava improved the knowledge of better } \\
\text { future prices to sell cassava produced }\end{array}$ & 4.53 & $2^{\text {nd }}$ \\
$\begin{array}{l}\text { Availability of marketing information exposed } \\
\text { are to better marketing outlets for cassava } \\
\text { produced }\end{array}$ & 4.50 & $3^{\text {rd }}$ \\
$\begin{array}{l}\text { The knowledge of marketing information } \\
\text { helps to reduce the risk with cassava } \\
\text { marketing }\end{array}$ & 4.35 & $4^{\text {th }}$ \\
$\begin{array}{l}\text { Availability of marketing information through } \\
\text { the extension agent is an incentive to } \\
\text { produce more cassava every year }\end{array}$ & 2.56 & $5^{\text {th }}$ \\
$\begin{array}{l}\text { Marketing information are not made } \\
\text { available when needed hence I cannot use it }\end{array}$ & 2.33 & $7^{\text {th }}$ \\
$\begin{array}{l}\text { Bad road condition is highly discouraging to } \\
\text { sell cassava produced at market due to high } \\
\text { transportation cost. }\end{array}$ & 2.40 & $6^{\text {th }}$ \\
$\begin{array}{l}\text { I don't have any opportunity to international } \\
\text { market for cassava produced }\end{array}$ & 2.07 & $8^{\text {th }}$ \\
$\begin{array}{l}\text { Marketing information on value addition is } \\
\text { confusing hence I don't use it }\end{array}$ & 1.67 & $9^{\text {th }}$ \\
$\begin{array}{l}\text { There is no significant improvement on my } \\
\text { economic gain as a result of utilization of } \\
\text { marketing information on cassava. }\end{array}$ & 1.51 & $10^{\text {th }}$ \\
\hline
\end{tabular}

\section{Figures in parentheses are percentages. WMS - Weighted Mean Score}

\section{Sources: Field Survey, 2012}

Table 5 revealed that majority $(69.1 \%)$ of the respondents were more favourably disposed to utilization of marketing information on cassava while $16.4 \%$ of the respondents were favourably disposed to utilization of marketing information and others (14.5\%) were less favourable in their disposition towards utilization of marketing information. This implied that 
the women farmers were favourably disposed to marketing information in their perception probably due to its inherent economic benefits.

Table 5: Categorization of respondents according to level of perception

\begin{tabular}{lcc}
\hline Perception categories & Frequency & Percentage \\
\hline Less favourable $(1.08-2.16)$ & 18 & 16.4 \\
Favourable $\quad(2.17-3.25)$ & 16 & 14.5 \\
More favourable (3.25 and & 76 & 69.1 \\
above) & & \\
\hline Grand Mean = 3.25
\end{tabular}

\section{Relationships between Selected Personal Characteristics of Women Farmers and Perception of Utilization of Marketing Information.}

Table 6 shows that there was positive and significant relationship between years of farming experience $(r=0.654, P \leq 0.05)$ and perception of utilization of marketing information. Conversely, there was negative and significant relationship between years spent in school $(r=-0.238, P \leq 0.05)$ and perception .of utilization of marketing information. This implies that the higher the years of farming experience of respondents, the more favourable they perceived the utilization of marketing information while the lower the years spent in school the more favourable the perception of the respondents on the utilization of marketing information. This finding is similar to that of Olaniyi et al (2011) who reported that there was significant relationship between farming experience and perception of utilization of agricultural information among rural youth in Oyo state, Nigeria.

Table 6: Summary of correlation analysis showing the relationship between selected personal characteristics of women farmers and perception on utilization of marketing information.

\begin{tabular}{llll}
\hline Variable & r- value & P- value & Remark \\
\hline Age & -0.023 & 0.814 & Not Significant \\
Years spent in school & $-0.238^{*}$ & 0.012 & Significant \\
Years of farming experience & $0.654^{* *}$ & 0.000 & Significant \\
Household Size & -0.115 & 0.230 & Not Significant
\end{tabular}

\section{*Significant @ 5\% $\quad$ ** Significant @ 1\%. Sources: Field Survey, 2012}




\section{Conclusion and Recommendation}

The study shows that marketing information were made available and utilized by women farmers through various identified sources especially through radio, husband, television and Mobile phones but they are less exposed to the use of modern ICTs such as internet to access marketing information on cassava. The finding also shows that women farmers often use marketing information on market days and market price information on cassava. The respondents are more favourable in their perception towards utilization of marketing information on cassava.

Based on the findings of this study, it was recommended that

1. The used of identified sources of marketing information should be concentrated on by extension institution for information delivery to women farmers in order to enhance their capacity for perception on utilization of marketing information on cassava.

2. More information should be made available on value addition and exportation of cassava to women farmers in the study area.

3. The extension institution should come up with market intelligence system for adequate marketing information delivery to women farmers in the study area.

\section{References}

Adebo, G. M., and Ewuola, S. O. (2005). Impact of Micro Credit and Effective Communication System on Income of Women in Ondo and Ekiti State, Nigeria. Journal of Agricultural Extension, 8, 158.

Ajayi, M.T. (2003). Analysis of Mass media Use for Agricultural Information by Farmers in Nigeria. Journal of Extension Systems 19(2): 45-55

Anigwe. O.F. (1990): Farm radio Listenership and agricultural Knowledge. A case Study of Akinyele Local Government Area of Oyo State. Msc Thesis, Department of Agricultural Extension and Rural Development, University of Ibadan, Ibadan.106pp

Banmeke, T.O.A. and Ajayi , M.T.(2006). Agricultural information Utilization pattern among Women Farmers in South West, Nigeria. In Proceedings of Annual Conference of International Research and Development Institute, Research and Development Network, June 28-29, 2006

Mangual, A (2010). " Access to Agricultural information" . The Pacific Agricultural and 
Forestry Policy network (PAFPNet), Land Resources Division News Article, Secretariat of The Pacific Community (SPC) 3pp.

Nosheen, F; Ali, T., Ahmad, M. and Nawaz, H. (2008). Exploring, the Gender Involvement in Agricultural Decision Making: a case study of District Chawal Pakistan Journal Of Agricultural Science 45(3) : 101 - 106.

Ogunlela, Y.I. and Muktar, A.A. (2009). Gender Issues in Agriculture and Rural Development in Nigeria: The Role of Women. Humanity and Social Sciences Journal 4 (1): 19-30

Olaniyi, O.A., Adebayo O. O and Akintola, S.O (2011). Rural Youth's Perception and Utilization of Agricultural Information in Oyo State, Nigeria. Journal of Agriculture and Social Sciences (JASS) 7(4): 117-123

Olowu, T.A. and Yahaya, M.K. (1998). Determination of Agricultural Information Needs of Women Farmers: A case study of North Central Nigeria. Journal of Extension Systems 2: 39-54

Oyeyinka, R.A. and Bello, R.O. (2013). Farmers Use of ICTs for Marketing Information Outlets in Oyo State, Nigeria. Journal of Agricultural Science; 5(11): 150-158

Saikia, S and Barman, U. (2013). Market Information Sources utilised by Farmers to Improve their Adoption Decisions on Sali Rice Technologies. Journal of Academic and Industrial Research 1(10): 641-644

Samuel, G.S. (2001). The Development of Integrated Management Information Systems for Agricultural Extension Institutions of Developing Countries: The case of Oromia Agricultural Development Bureau of Ethiopia, Aachen: Shaker. pp.18-33

Yahaya, M.K. and Akinboye, O.A (1999). Assessment of Information Needs and Media Use Pattern of Crop Farmers in Afijio Local Government Area of Oyo State. Lesson for Appropriate Extension Packaging, A paper presented at the $5^{\text {th }}$ Annual Conference of Agricultural Extension Society of Nigeria (AESON) held at the University Nigeria, Nsukka, 13-16 ${ }^{\text {th }}$ April 1999.

Yahaya, M.K. (2002). Gender and Communication Variables in Agricultural Information Dissemination in Two Agro-ecological Zones of Nigeria. Corporate Graphics Ltd, Ibadan. Pp 20-23 